\title{
H.F. Stander
}

\section{THEFT AND ROBBERY IN CHRYSOSTOM'S TIME}

\begin{abstract}
The aim of this article is to study what Chrysostom said about theft and robbery in his community. His homilies on the New Testament will be scrutinized for information on this negative feature of the ancient world, since homilies are always important sources for information on social issues. It becomes clear that house-breaking was quite common, and that robberies were often associated with violence. Even tombs were robbed and were plundered of valuables. Robbers were severely punished and for a single theft one could spend the rest of one's life in prison. Prisoners were also dependent on their family or on the charity of Christians for food. But Chrysostom also looked at robbery from a theological point of view. He ascribed it to the working of demons. When we are robbed, we are confronted with various choices: we can curse the robber, or we can plot against him, or we can thank God. This study will make a contribution to our knowledge of the social history of the ancient world.
\end{abstract}

\section{INTRODUCTION}

When scholars speak about wealth and possessions in the ancient world, they usually refer to either the accumulation of wealth, or to the distribution of wealth, such as almsgiving. These are voluntary acts. But there is also another phenomenon which can cause an owner to be separated from his possessions, and that is theft or robbery. Robbery is the shady side of economy, wealth and possessions. This study will deal with this dark aspect of the ancient economical world. I will focus on what Chrysostom tells us in his homilies on the New Testament concerning theft and robbery.

Homilies are very important sources for information on social history (cf. Allen \& Mayer 1993:260). Mayer (2008a:567) says that homilies give us access to the daily life of the world in which they played a role. This paper will shed light on an economical issue in the ancient world which has never been properly studied.

Prof. Hennie F. Stander, Departement Antieke Tale, Universiteit van Pretoria. 


\section{VARIOUS FORMS OF ROBBERY}

Robbery was very common in Chrysostom's community and could take on various forms. There were, for example, pickpockets. Chrysostom says that they call such a person a 'cut-purse' ( $\beta a \lambda \alpha \nu \tau$ тото, $\mu$ o') since he cuts through a purse $\left(\beta a \lambda \alpha, \nu \tau \iota \mathrm{\nu} \delta\llcorner\alpha \tau \epsilon \mu \omega, \nu)\right.$ and then takes the gold. ${ }^{1}$ Travelling in the ancient world was dangerous, and travellers could fall victim to the forces of nature at sea or on land (Grossmark 2006:57; cf. also Leyerle 2000:462), and they also faced the risk of meeting robbers or pirates ( $\left.\pi \in \iota \rho a \tau \alpha^{\prime},\right)^{2}{ }^{2}$ Robbery was even to be found within the Church. ${ }^{3}$ Even alms were stolen. ${ }^{4}$ Chrysostom ${ }^{5}$ says that he cannot believe the accusation that priests too steal, but Kazhdan(1991:2033) says that hagiographical texts often relate cases of theft even in monasteries.

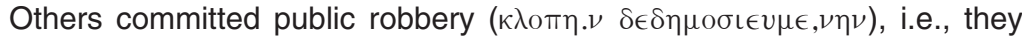
robbed the state. ${ }^{6}$ Jury men were also guilty of robberies because of their frauds

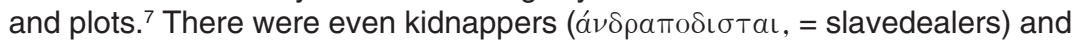
destroyers (lumew/nej) who stole children by seducing them by promising pleasures. ${ }^{8}$ It often happened that servants would rob their masters. ${ }^{9}$ These slaves often ran away after they had robbed their masters, and that enraged their masters. ${ }^{10}$ Chrysostom says that one should not think that women do not rob or steal. They could do it through means of their husband. ${ }^{11}$

Pohl (2006:26) says that in Late Antique society, violent behaviour was highly organized and involved well-trained war-bands and armies. This also becomes clear in Chrysostom's writings since he says that robbers often operated in groups and formed bands ( $\pi \epsilon \iota \rho \alpha \uparrow \eta, \rho\llcorner O \nu) .{ }^{12}$ They would then elect a captain of the bands. ${ }^{13}$

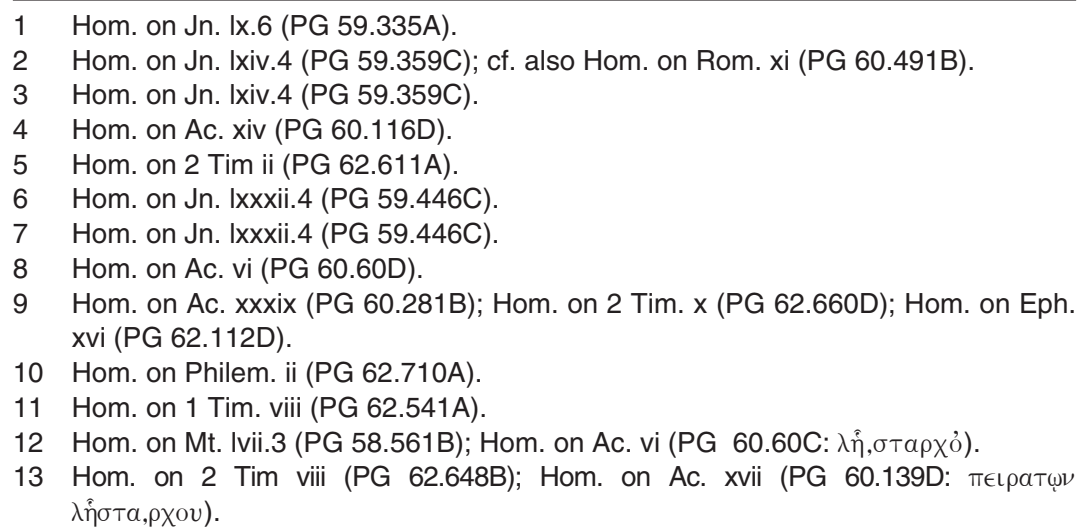




\section{HOUSEBREAKING}

Housebreaking was a reality. When night arrived, the occupants in the house were in fear of the possibility to be robbed and even to be killed. ${ }^{14}$ Robbers and violators of tombs definitely preferred to strike at night. ${ }^{15}$ Home owners had to take various precautionary steps to prevent housebreaking. They, for example, would light a candle $(\lambda v, \chi \nu$ ov $\kappa \in \iota \mu \epsilon, \nu \mathrm{O} v)$ so that thieves could not enter the house for fear of being caught. ${ }^{16}$ They would also lock the doors with bolts ( $\mu \circ \chi_{\lambda o r}$, ), and put bars against the doors, ${ }^{17}$ and often there were even guards ( $\phi v, \lambda \alpha \kappa \epsilon \epsilon)$ and outer guards ( guards and night police (cf. Kazhdan 1991:2033). House owners would even arm themselves to ward off the attacks of robbers (cf. Jeffreys 1991:644). ${ }^{19}$ They also had dogs to bark against robbers. ${ }^{20}$ Magical signs (such as a drawing of the magic eye on a wall) were also used to ward off, or to discover the thief (Kazhdan 1991:2033). But all these precautionaries did not help.

A housebreaker ( $(\mathrm{o} \chi \chi \omega \rho v, \chi 0)$ ) would cut though the wall ( or $\delta$ L $\rho v, \tau T \in \mathrm{L}$ TOL, $\chi \mathrm{O} \cup)^{21}$ and rush into the chamber. ${ }^{22}$ Often robbers would wear a mask ( $\pi \rho \circ \sigma \omega \pi \epsilon ! \circ \nu)$ to conceal their faces ${ }^{23}$ when they broke through

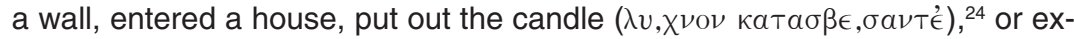

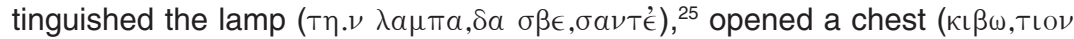

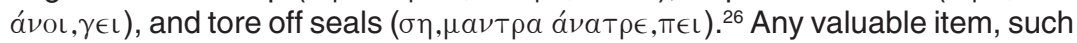

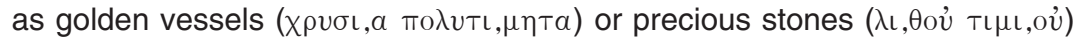
could be stolen. ${ }^{27}$ They would then carry off their booty. ${ }^{28}$

14 Hom. on Mt. Ixix.4 (PG 58.653D); Hom on Philipp. iii (PG 62.195D).

15 Hom. on Mt. Ivii.5 (PG 58.564C); 1 Thess. ix (PG 62.449B-C).

16 Hom. on Eph. xviii (PG 62.122B).

17 Hom. on Mt. Ixix.4 (PG 58.653D); Hom. on 1 Cor. xv.ii (PG 61.127BC). The ancients did not only make use of sliding and turning key-lock systems, but they also made extensive use of portable padlocks (cf. Vikan 1991:1243-4).

18 Hom. on Thess. I (PG 62.396B-C).

19 Hom. on 1 Thess. ix (PG 62.450C).

20 Hom. on Ac. xvii (PG 60.139D).

21 Hom. on Jn.lx.6 (PG 59.335A); Hom. on Ac. xxv (PG 60.195B); Hom. on Rom. ix

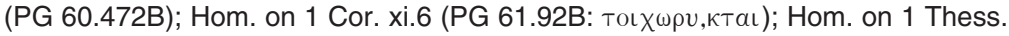
$x$ (PG 62.460C).

22 Hom. on 1 Thess. iii (PG 62.413B).

23 Hom. on Jn. Ix.5 (PG 59.334D).

24 Hom. on 1 Cor. xi.6 (PG 61.92B).

25 Hom. on 1 Thess. xi (PG 62.462B-C).

26 Hom. on 1 Thess. $x$ (PG 62.460C).

27 Hom. on 1 Thess. iii (PG 62.413B).

28 Hom. on 1 Thess. iii (PG 62.413B). 
When the house owner noticed that he was robbed, he would run after the robbers and would even call others to stop them. ${ }^{29}$ But if he saw that he could not overtake the thief, he would stop running. The victims would nevertheless curse the robber, or plot against him. ${ }^{30}$ The best remedy against robbery is not to gather too much wealth. ${ }^{31}$ One should not fill one's vessel with overwhelming cargo. If you are lightly equipped, you have nothing to fear.

\section{VIOLENCE}

It is clear from Chrysostom's homilies that robberies were often associated with violence. ${ }^{32}$ Robbers were often armed. ${ }^{33}$ They could carry a sword and

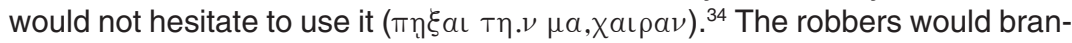
dish their sword ( $\left.\mu \alpha, \chi \alpha \iota \rho \alpha \nu \epsilon^{\prime} \pi \iota \epsilon \in, \omega \nu\right)$ at their victims, and threatened them with death. ${ }^{35}$ They often injured their victims. ${ }^{36}$ People lived in fear of being killed by robbers who broke into their houses. ${ }^{37}$ That is why house owners had to arm themselves to be able to defend themselves against the attacks of robbers. Many ancient sources indicate that violence occupied a prominent place in ancient cultures, but Zimmermann (2006:351-352) says that it is definitely not accurate to claim that ancient cultures were more violent than others.

\section{THE ROBBING OF TOMBS}

Not even in one's death could one flee from robbers, for robbers also burst

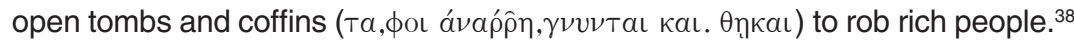
It was very common to rob tombs $(\tau v \mu \beta \omega \rho v, \chi \omega \nu) .{ }^{39}$ Grave-robbing refers to various crimes such as the desecration of burial places, the plundering of valuables, the theft of building material, and even the unauthorized exhumation

29 Hom. on 2 Tim. x (PG 62.662C).

30 Hom. on Jn. Ixxi.3; (PG 59.388A).

31 Hom. on Eph. xiii (PG 62.98D).

32 Hom. on Jn. Ix.5-6; (PG 59.334D-335A).

33 Hom. on Rom. xi (PG 60.487A).

34 Hom. on 1 Thess. ix (PG 62.450C).

35 Hom. on Mt. Ixvi.3 (PG 58.629D).

36 Hom. on Mt. lii.5 (PG 58.523C).

37 Hom. on Philipp. iii (PG 62.195D; Hom. on Rom. ix (PG 60.472B).

38 Hom. on 1 Cor. xxxv.13 (PG 61.304C).

39 Hom. on Mt. xxxvi,4 (PG 57.418D); Hom. on Mt. Iv,2 (PG 58.542C); Hom. on Mt. Ixxxvii,4 (PG 58.774B); Hom. on Rom. ii (PG 60.491A); Hom. on Rom. iii (PG 60.415A); Hom. on Rom. vii (PG 60.448D); Hom. on Rom. xi (PG 60.491B); Hom. on Eph. viii (PG 62.57B); Hom. on Philipp iii (PG 60.491A); Hom on 2 Thess. i (PG 62.472B); Hom. on Jn. xxxiii.3 (PG 59.192D). 
of corpses (Burgmann \& Kazhdan 1991:867). These tomb-violators would even strip the body of its grave-clothes, and take the coffin also, and leave the corpse naked and in the open. ${ }^{40}$ This was done to get hold of wealth which was buried with the corpse. ${ }^{41}$

Though the robbing of tombs was so common, Chrysostom argues that it was unlikely that the body of Christ could have been stolen. ${ }^{42} \mathrm{He}$ has many arguments to prove his point. In the first place there was a seal upon the tomb. There were also many watchmen and soldiers. Chrysostom's most important argument is that there was no motive for stealing the body. Why would anybody have done it? They would definitely not do it to feign the doctrine of the resurrection, since such a doctrine would not even enter their mind.

Then Chrysostom uses another very interesting argument which discloses to us how corpses were prepared for burial in his time. He says that napkins were stuck on the body with myrrh. It was therefore unlikely that the disciples would steal the body, since it would take too much time to strip the body, and it would be regarded as a dishonouring of the body to steal it naked. He says:

Especially when it was myrrh, a drug that adheres so to the body, and cleaves to the clothes, whence it was not easy to take the clothes off the body, but they that did this needed much time, so that from this again, the tale of the theft is improbable. ${ }^{43}$

Elsewhere ${ }^{44}$ Chrysostom again says that corpses were buried with much myrrh, "which glued linen to the body not less firmly than lead". Chrysostom then argues that one cannot even listen to those who argue that the body of Jesus was stolen. It would take a thief a long time to undo the clothes and they would know that they would then not be able to escape detection if they had done so.

\section{THE CHARACTER OF ROBBERS}

Robbers are not completely evil, and do have virtues as well. ${ }^{45}$ Evil cannot subsist if it does not have some good. Robbers, for example, are not devoid of conscience in their dealings, and they do have some shame. That is why

40 Hom. on 1 Cor. xxxv.13 (PG 61.304D).

41 Cf. Hom. on 1 Cor. xxxiv.9 (PG 61.293D).

42 Hom. on Mt. xc,1 (PG 58.787C-789B).

43 Hom. on Mt. xc,1 (PG 58.788D-789A).

44 Hom. on Jn. Ixxxv.4 (PG 59.465A-B).

45 Hom. on Ac. ii (PG 60.32D). 
they do not steal openly. ${ }^{46}$ One can also find concord amongst robbers ${ }^{47}$ and they can even display love..$^{48}$ But this type of love stems from an impure heart, which is false and hypocritical.

Robbers always live in fear and can look no one in the face with confidence. ${ }^{49}$ They are shameful of their acts. That is why they wear a mask, and commit their misdeeds clandestinely under a veil of solitude and darkness. ${ }^{50}$ They are not satisfied with what they possess, and even look upon the sun itself with suspicion. ${ }^{51}$ Robbers often rob rich people, ${ }^{52}$ but they also rob people who are poorer than themselves. ${ }^{53}$

\section{PUNISHMENT}

Punishment could be very severe. Chrysostom says that one should not think that because the sin is committed in a moment, that therefore the punishment too should be a matter of a moment. ${ }^{54} \mathrm{He}$ says that it happens that for a single theft, one could spend your whole life in prison, or in the mines. According to a study by Tovar (2006:103, 107-108) conditions in the prisons were very difficult, and people could die in prison. The worst problem was hunger. Prisoners were not provided any food at all by the prisons, and were dependent on their friends and family or the charity of Christians. This is confirmed by a remark of Chrysostom who says that life was often very hard for these convicts, because they could struggle with continual hunger and every kind of death..$^{55} \mathrm{He}$ says that if a man steals another's garment, or cut his purse, his sides are flayed ( $\tau{ }^{\prime}$ '.

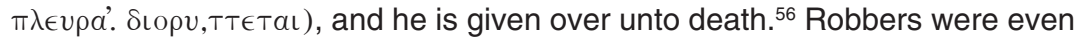
tortured $(\beta a \sigma a \nu \iota \zeta \epsilon, \sigma \theta \omega)$ and racked $(\sigma \tau \rho \in \beta \lambda o v, \sigma \theta \omega) .{ }^{57}$

Chrysostom says that thieves who are caught, should give fourfold of what they have stolen. If, however, they used violence when they stole, they should give tenfold and much more. ${ }^{58}$ Robbers $(\lambda \hat{\eta} \sigma \tau a l$,$) and tomb-breakers$

\footnotetext{
46 Hom. on Ac. ii (PG 60.32D).

47 Hom. on Mt. xxxv.1 (PG 57.405B).

48 Hom. on 2 Cor. xxvii.3 (PG 61.587A); Hom. on 1 Tim. ii (PG 62.509D).

49 Hom. on $1 \mathrm{Tim}$. xii (PG 62.560B).

50 Hom. on Jn. Ix.5 (PG 59.334D).

51 Hom. on 1 Tim. xii (PG 62.560B).

52 Hom. on 1 Tim. xvii (PG 62.594D); Hom. on 1 Tim xviii (PG 62.598D).

53 Hom. on 1 Thess. $x$ (PG 62.460D-461A).

54 Hom. on 1 Cor. ix.2 (PG 61.77A).

55 Hom. on 1 Cor. ix.2 (PG 61.77A).

56 Hom. on 1 Cor. xii.9 (PG 61.102C).

57 Hom. on Eph. xiv (PG 62.102D).

58 Hom. on Mt. lii.5 (PG 58.525A).
} 
$(\tau v \mu \beta \omega \rho v, \chi \circ)$ ) were scourged ( $\mu \alpha \sigma \tau \iota \gamma о u \nu \tau \alpha)$, and were also put in prison. ${ }^{59}$ Punishment could even include the mutilation of limbs (Kazhdan 1991:2033). When they were brought to court, they sank with terror. They knew that death was imminent. ${ }^{60}$ Late Antiquity was notorious for legitimized violence and several theologians gave arguments in its support (Clark 2006:137-146).

Chrysostom tells us that when you find your goods in someone's possession, you may demand satisfaction from that person, while the person who had stolen the goods, is acquitted. ${ }^{61} \mathrm{He}$ adds that though "ten thousand

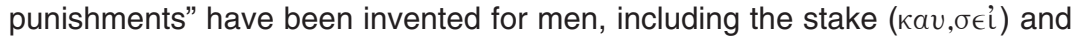
the rack ( $\beta a \sigma \alpha, \nu \circ u)$, they would scarcely ever hang a woman, but limit men's anger to smiting her on the cheek. ${ }^{62}$ If she is pregnant, and it is absolute necessary for her to be hung, they would still not, out of respect, hang her. While it is a disgrace for a man to strike a woman, it is a much greater disgrace for a woman to smite a woman. Therefore, if a woman steals, one should merely watch her, and take care of your goods, but you should not punish her. ${ }^{63}$

\section{SPIRITUAL ROBBERY}

Robbery should not merely be defined as "taking the property of others". A covetous person $(\pi \lambda \epsilon O \nu \epsilon, \kappa T \eta \dot{)}$ can also be regarded as a thief $(\kappa \lambda \epsilon, \pi \tau \eta \dot{\eta})$ or robber $(\lambda \hat{\eta} \sigma \tau \eta),,{ }^{64} \mathrm{He}$ is even worse than robbers since robbers steal at night, but covetous people are shameless and steal with an open face in the middle of the market-place. ${ }^{65} \mathrm{~A}$ covetous person commits fraud and carries off his spoils with confidence out of the door in the sight of those whom he has injured. The actions of such a man are therefore more shameless (ávaı $\sigma \chi v \nu 0, \tau \in \rho O ̉)$ and ty-

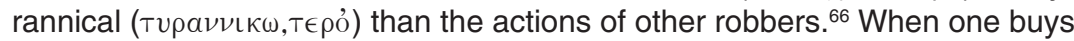
and sells and tries to pay less than the value, one is also guilty of robbery ${ }^{67}$

Adultery is also a form of robbery. ${ }^{68}$ It is even crueller than ordinary robbery. That is why someone whose marriage is invaded, grieves much more than one whose riches were carried off.

\footnotetext{
59 Hom. on Jn. Ix.5 (PG 59.334D); Hom. on Heb. xxix.2 (PG 63.204B).

60 Hom. on 2 Tim. v (PG 62.629A).

61 Hom. on 1 Cor. xv.11 (PG 61.127D).

62 Hom. on Eph. xv (PG 62.109D-110A).

63 Hom. on Eph. xv (PG 62.110A-B).

64 Hom. on 1 Thess. $x$ (PG 62.460B-C).

65 Hom. on 1 Thess. $x$ (PG 62.460C).

66 Hom. on 1 Thess. $x$ (PG 62.460C-D).

67 Hom. on Jn. Ix.6 (PG 59.335A).

68 Hom. on 1 Thess. v (PG 62.424C).
} 


\section{THEOLOGICAL REFLECTION}

Robberies do not take place without the working of a demon. Chrysostom says that it is a demon who arms the robbers. ${ }^{69}$ The demon even knows where our treasures are. And if the demon sees that we grieve at the loss, he will attack us again. But if we despise the act and laugh at it, the demon will stop doing it. ${ }^{70}$ One can nevertheless argue, according to Chrysostom, that it was God who took away from you that which the robber had stolen. ${ }^{71}$ That is also what Job did when the devil took away all his possessions. Job then said: "The Lord has taken away."

There is no difference between petty theft and the theft of large items. ${ }^{72}$ Similarly, there is no difference between the theft of gold and the theft of silver. Your motive is the same. It is only a matter of coincidence that one steals something small, because if you had the opportunity to steal something big, you would also have stolen that. ${ }^{73}$ Chrysostom bases his argument on the fact that the widow who threw in two mites, did not contribute less than they who cast in gold. God judges the intention ( $\pi \rho \circ \propto \iota \rho \in, \sigma i),{ }^{74}$ and not the amount of the gift. And if this principle applies to almsgiving, it must also apply to wrongful dealings. If the widow who contributes two mites is considered to be equal to the greatest givers, because of her good intention, similarly he who steals two mites is as culpable as those robbers of big things. ${ }^{75}$

But then Chrysostom argues that actually it is worse to steal small items than large items. ${ }^{76}$ To prove his point, he says that a drunkard who has become drunk after drinking bad wine, is actually worse than a drunkard who has drunken good wine, since in the case of the latter the drunkard does actually have a good excuse! ${ }^{77}$ Chrysostom says that we should remember to always judge the intention, and not the act, if one wants to know whether something is right or wrong.

It is not poverty that causes robbery. Poverty compels us to work. Theft is caused by idleness. ${ }^{78}$ Covetousness and the tendency not to neglect one's

\footnotetext{
69 Hom. on 1 Thess. iii (PG 62.414B-C).

70 Hom. on 1 Thess. iii (PG 62.414C).

71 Hom. on 1 Thess. iii (PG 62.413C).

72 Hom. on 2 Tim. iii (PG 62.617B-C).

73 Hom. on 2 Tim. iii (PG 62.617B-C).

74 See also Hom. on Jn. Ix.6 (PG 59.335A).

75 Hom. on 2 Tim. iii (PG 62.617C-618A).

76 Hom. on 2 Tim. iii (PG 62.618A-B).

77 Hom. on 2 Tim. iii (PG 62.618B).

78 Hom. on Eph. iii (PG 62.20C).
} 
own interests, and to seek the interests of others, lead to robbery. ${ }^{79}$ Chrysostom's advice to those who have been robbed, is to merely give away what remained after the robbery. ${ }^{80}$ One should lighten your ship in order to survive. One tends to cling to that which was not stolen, but that is almost like filling the ship with water.$^{81}$ However, to give your money to the voluntary poor was regarded as more attractive than to give to those who suffer from involuntary poverty (Mayer 2008b).

Though a rich man can be reduced to poverty by the attacks of robbers, a Christian can never be robbed of his virtue..$^{82}$ One should not feel arrogant by the fact that you yourself do not steal. If you examine your own life, you would find out that though you don't steal $(\kappa \lambda \epsilon, \pi \tau \epsilon i)$, you are still rapacious

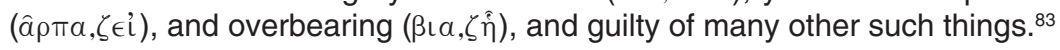

It was regarded as a disgrace to be robbed. ${ }^{84}$ But the one who is being robbed, is not the only unhappy person, since the robber himself is unhappy. The latter is unhappy either because he knows there will be a future judgement, or, if he does not believe in it, he is unhappy because of his feel of shame. ${ }^{85}$ Furthermore, one should never think that one may commit robbery in order to give alms. Such an act cannot be called robbery. It should be called harsh-

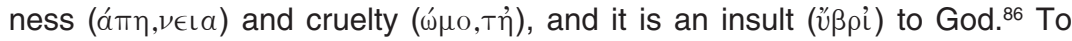
prove his point, Chrysostom refers to Cain who insulted and offended God when he brought inferior gifts to him.

Love can overcome robberies. Nobody would, for example, rob someone whom they love, but would rather give him his own possessions. ${ }^{87}$ Christ could transform the life of a robber. He, for example, declared that a thief could become a citizen of Paradise. ${ }^{88}$

The best remedy against any urge to steal or to do anything wrong, is to continually think of the Day of Resurrection and of the Judgment-seat (To.

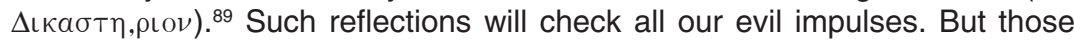

79 Hom. on Mt. Ixxvii.6 (PG 58.710C); Hom. on Mt. Ixxx.3 (PG 58.727D); cf also Hom. on 1 Cor. xv.11 (PG 61.127B-C).

80 Hom. on 1 Thess. iii (PG 62.414D-415A); cf. also Hom. on Eph. xxii (PG 62.156D).

81 Hom. on 1 Thess. iii (PG 62.415A).

82 Hom. on 1 Tim. xviii (PG 62.599A).

83 Hom. on 2 Tim. ii (PG 62.611B-C).

84 Hom. on Eph. xxii (PG 62.157A).

85 Hom. on 2 Tim. v (PG 62.628C).

86 Hom. on 2 Tim. vi (PG 62.634B).

87 Hom. on 2 Tim. vii (PG 62.640C).

88 Hom. on Jn. xii.2 (PG 59.83D).

89 Hom. on Jn. xlv.3 (PG 59.255D). 
who steal or covet will not be allowed to enter the Kingdom of God. ${ }^{90}$ We can see this principle in our everyday life as well: when a soldier acts unworthily towards his king, he is not allowed to see the king.

One should thank God and glorify him when we are being robbed, and God will always reward us. ${ }^{91}$ Do not think that since you were a victim, you had no choice, and therefore one cannot expect God's favour. Everyone who has been robbed does have a choice. We can choose to be discontented, or impatient, or utter ten thousand curses against the robber, or to speak ill of him, or to plot against him, or we can choose to thank God. That is why God will reward us, for deciding to make a sound choice..$^{92}$ One may not refrain from giving a loaf of bread or a few pence to a robber. ${ }^{93}$ God ordered us to pray for peace and the good estate of the world. We are thus ordered to pray on behalf of all men, and this means that we should also pray for robbers and the violators of tombs.

\section{CONCLUSION}

Robberies and theft were as common in Chrysostom's world as it is today in our modern world. Robberies could take on many different forms, from pickpocketing to housebreaking and the robbing of tombs. Crime was often accompanied by violence. Good citizens took precautionary steps, but the criminals always tried to outwit them. Nevertheless, severe punishment awaited the criminals in Chrysostom's time. It was again clear from this study that homilies can give us very interesting information on the social life of contemporary society.

90 Hom. on Jn. I.3 (PG 59.282B).

91 Hom. on Jn. Ixxi.3 (PG 59.387D-388A).

92 Hom. on Jn. Ixxi.3 (PG 59.387D-388A).

93 Hom. on Rom. xxi (PG 60.607A). 


\section{BIBLIOGRAPHY}

Allen, P. \& Mayer, W.

1993. Computer and homily: Accessing the everyday life of early Christians. VC 47:260-280.

Burgmann, L. \& Kazhdan, A.P. 1991. Grave-robbing. In: A.P. Kazhdan (ed.), The Oxford Dictionary of Byzantium (Oxford: Oxford University Press), p. 867.

ClaRK, G. 2006. Desires of the hangman: Augustine on legitimized violence. In: H.A. Drake (ed.), Violence in Late Antiquity. Perceptions and practices (Aldershot: Ashgate), pp. 137-146.

Grossmark, T. 2006. The inn as a place of violence and danger in rabbinic literature. In: H.A. Drake (ed.), Violence in Late Antiquity. Perceptions and practices (Aldershot: Ashgate), pp. 57-68.

JEFFREYS, M.J. 1991. Dogs. In: A.P. Kazhdan (ed.), The Oxford Dictionary of Byzantium (Oxford: Oxford University Press), p. 644.

KAZHDAN, A.P. 1991. Theft. In: A.P. Kazhdan (ed.), The Oxford Dictionary of Byzantium (Oxford: Oxford Univ. Press), p. 2033.

LEYERLE, B. 2000. Communication and travel. In: P.F. Esler (ed.), The Early Christian World (London: Routledge), pp. 452-474.

MAYER, W.

2008a. Homiletics. In: S.A. Harvey \& D.G. Hunter (eds.), The Oxford Handbook of Early Christian Studies (Oxford University Press), pp. 565-583.

2008b. Poverty and generosity toward the poor in the time of John Chrysostom. In: S.R. Holman (ed.), Wealth and poverty in Early Church and society (Grand Rapids: Baker Academic), pp. 140-158.

POHL, W. 2006. Perceptions of barbarian violence. In: H.A. Drake (ed.), Violence in Late Antiquity. Perceptions and practices (Aldershot: Ashgate), pp. 15-26.

TOVAR, S.T. 2006. Violence in the process of arrest and imprisonment in Late Antiquity. In: H.A. Drake (ed.), Violence in Late Antiquity. Perceptions and practices (Aldershot: Ashgate), pp. 103-112.

VIKAN, G.

1991. Locks and padlocks. In: A.P. Kazhdan (ed.), The Oxford Dictionary of Byzantium (Oxford: Oxford University Press), pp. 1243-1244. 
ZiMmeRMANN, M.

2006. Violence in Late Antiquity reconsidered. In: H.A. Drake (ed.), Violence in Late Antiquity. Perceptions and practices (Aldershot: Ashgate), pp. 343-357.

Keywords

Chrysostom

Homilies

Robbery

Social history
Trefwoorde

Chrysostomos

Preke

Rowery

Sosiale geskiedenis 